\title{
TRANSPORT OF SPERMATOZOA FROM SEMINIFEROUS TUBULES TO EPIDIDYMIS IN THE MOUSE: A HISTOLOGIGAL AND QUANTITATIVE STUDY
}

\author{
BRUCE M. BARACK* \\ Department of Anatomy, Washington University School of Medicine, \\ St. Louis, Missouri, U.S.A.
}

(Received 1st May 1967)

\begin{abstract}
Summary. The histology and structure of the seminiferous tubules, the tubuli recti, the rete testis and the ductuli efferentes of the adult albino mouse were studied in conjunction with the effect of unilateral ligation of the ductuli efferentes on the testis of the operated side under various experimental conditions.

Results indicate that the amount of fluid produced within the testis is sufficient to flush the tubular system at least once a day and therefore eight times/spermatogenic cycle and that this fluid passage is the major factor in the transport of spermatozoa from the seminiferous tubules to the ductuli efferentes. The possibility of an interaction between the Sertoli cell and associated spermatids in early spermiogenesis resulting in secretion of fluid by the Sertoli cell is discussed.
\end{abstract}

\section{INTRODUCTION}

The mechanism of transport of immotile spermatozoa from the seminiferous tubules to the epididymis is still in question. The consequences of unilateral ligation of the ductuli efferentes or the head of the epididymis on the testis of the operated side have been described by Van Wagenen $(1924,1925)$, White (1933), Harrison (1953) and Harrison \& Macmillan (1954) in the rat; Ladman \& Young (1958) in the guinea-pig; Baillie (1962) in the mouse and Gaddum \& Glover (1965) in the rabbit. These investigators found that following ligation there occurs a generalized dilatation of the seminiferous tubules accompanied by a varying degree of shedding and/or degeneration of the seminiferous epithelium. An increase in the wet weight of the testis was always observed initially when this parameter was measured. These findings suggest that fluid secretion into the seminiferous tubules is a major propulsive force in the transport of spermatozoa from seminiferous tubules to epididymis. Other investigators (Von Mollendorff, 1920; Toothill \& Young, 1931; Mason \& Shaver, 1952; Clermont, 1958; Macmillan \& Harrison, 1955; Macmillan \& Aukland, 1960; Roosen-Runge, 1961; Leeson, 1962; Scott, Wales, Wallace

* Ford Foundation Fellow in Reproductive Research. 
\& White, 1963; Marin-Padilla, 1964; Holstein \& Weiss, 1967) using different methods have also made reference to sperm transport.

An incidental finding in our laboratory was that the wet weight of the right testis of the mouse was only slightly greater than the wet weight of the left testis (see Table 1). Therefore it was thought that if the ductuli efferentes were unilaterally ligated, the wet weight of the testis on the operated side could be determined at different periods of time and compared with the wet weight of the unoperated testis which would serve as a control. The difference in weight between the two testes would thus represent some measure of the amount of fluid normally flowing through the seminiferous tubules, the tubuli recti and the rete testis in a given period of time. Unilateral ligation of the ductuli efferentes was subsequently performed on four groups of adult mice: normal animals, normal animals injected with different hormones, cryptorchid animals and hypophysectomized animals.

In order to appreciate more fully the course taken by spermatozoa in passing from the seminiferous tubules to the epididymis in the mouse, the histology of the seminiferous tubules, the tubuli recti, the rete testis and the ductuli efferentes was studied by light microscopy. The findings of these studies are reported below, and presented in two parts.

\section{PART 1: THE ANATOMY OF THE RETE TESTIS IN THE MOUSE Materials and methods}

Swiss albino male mice, 8 to 9 weeks old, were bred in our laboratory and used throughout these studies except where noted. For histological study, appropriate pieces of testicular tissue of approximately $2 \mathrm{~mm}^{3}$ in size were obtained from five animals. The pieces were selected to include the area of penetration of the tunica albuginea by the rete testis and the testicular vessels, as well as a portion of the ductuli efferentes. Additional pieces of epididymal tissue were taken from three animals to include the course of the ductuli efferentes into the head of the epididymis and into the epididymal duct.

Tissue was fixed in either Helly's solution or buffered osmic acid, dehydrated in cellosolve and methylsalicylate and embedded in ester wax. Three-micron serial sections were cut on a Porter-Blum microtome using a glass knife. The sections were stained with iron haematoxylin, differentiated in picric acid and counterstained with fast green.

\section{Histological observations (Plates 1 and 2)}

The region between a seminiferous tubule and a straight tubule possesses seminiferous epithelium in continuity with a short segment of Sertoli cells. The epithelium of the straight tubule is composed entirely of Sertoli cells. The vacuolated cytoplasmic processes of these cells extend into the lumen of both the straight tubule and the rete extension to form a plug or valve in the straight tubule. Material fixed in buffered osmium tetroxide failed to reveal fat in these cells. In most straight tubules the cytoplasmic processes occlude the lumen. In the few with a patent lumen desquamated cells and spermatozoa are always present.

The rete extension, which is continuous proximally with the straight tubule 

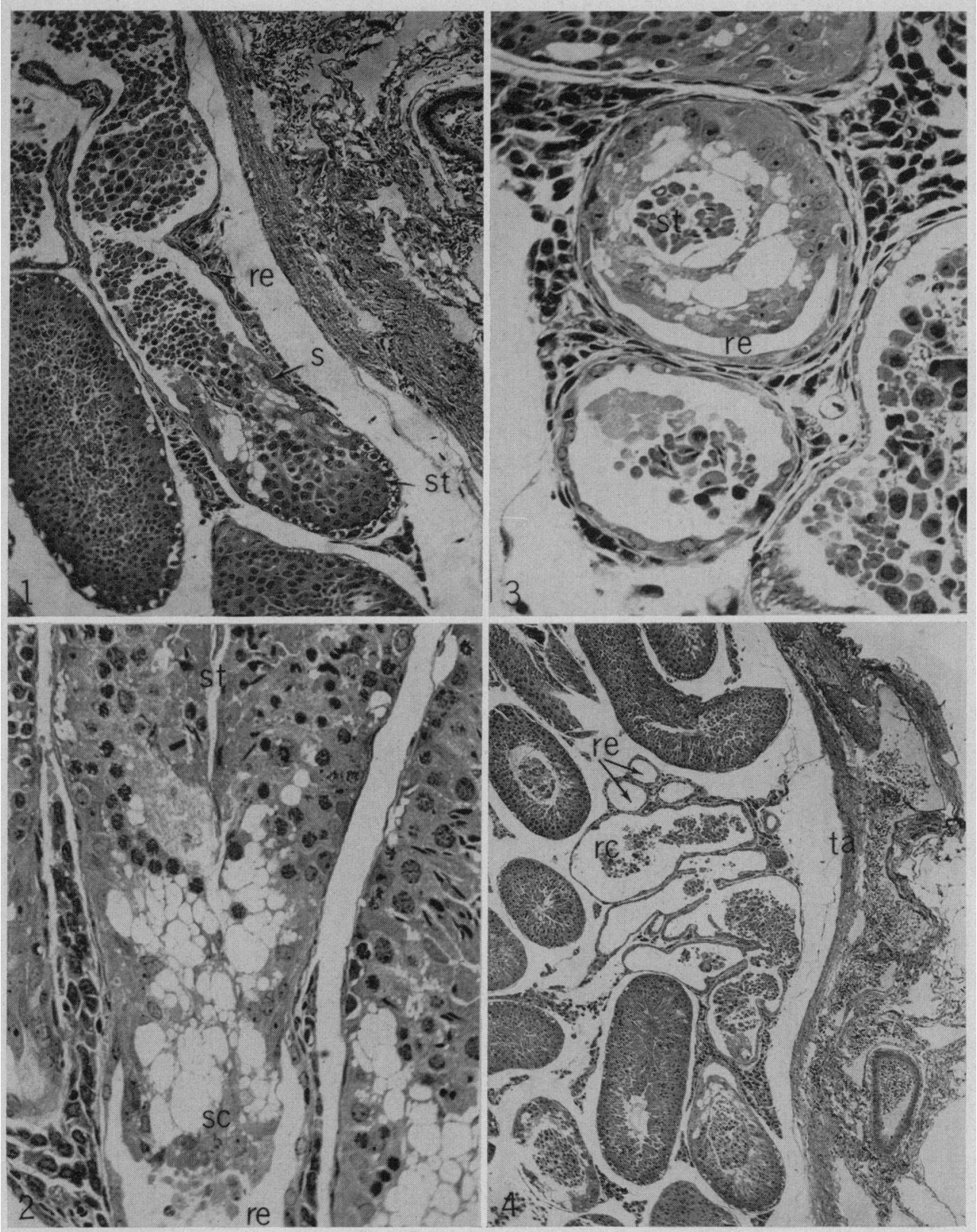

Fir. 1. A seminiferous tubule (st) is continuous with a straight tubule (s) composed t'ntirely of Sertoli cells. "The vacuolated cytoplasmic processes of the Sertoli cells project into the lumen of the rete extension (re). (ierminal cells are alwavs seen in the lumen of the straight tubule when it is patent. 150 .

Fic. 2. In the majority of straight tubules, the lumen is occluded by the Sertoli cells sce. thus preventing reflux of spermatozoa from the rete extension (re) to the seminiferous tubule (st). 330 .

ligs. 3. The lumen of the straight tubule (st) actually extends inte the lumen of the rete extension (re) due to the projection of the cytoplasmic processes of the Sertoli cells. The rete extension is lined by low cuboidal epithelium and is surrounded by a continuous: single layer of squamous cells. $\times 330$.

Fin. 4. The narrow rete extensions (re) join one of several large rete chanuels (re located immediately subjacent to the tunica albuginea (ta). 70 . 
PLA'TE 2

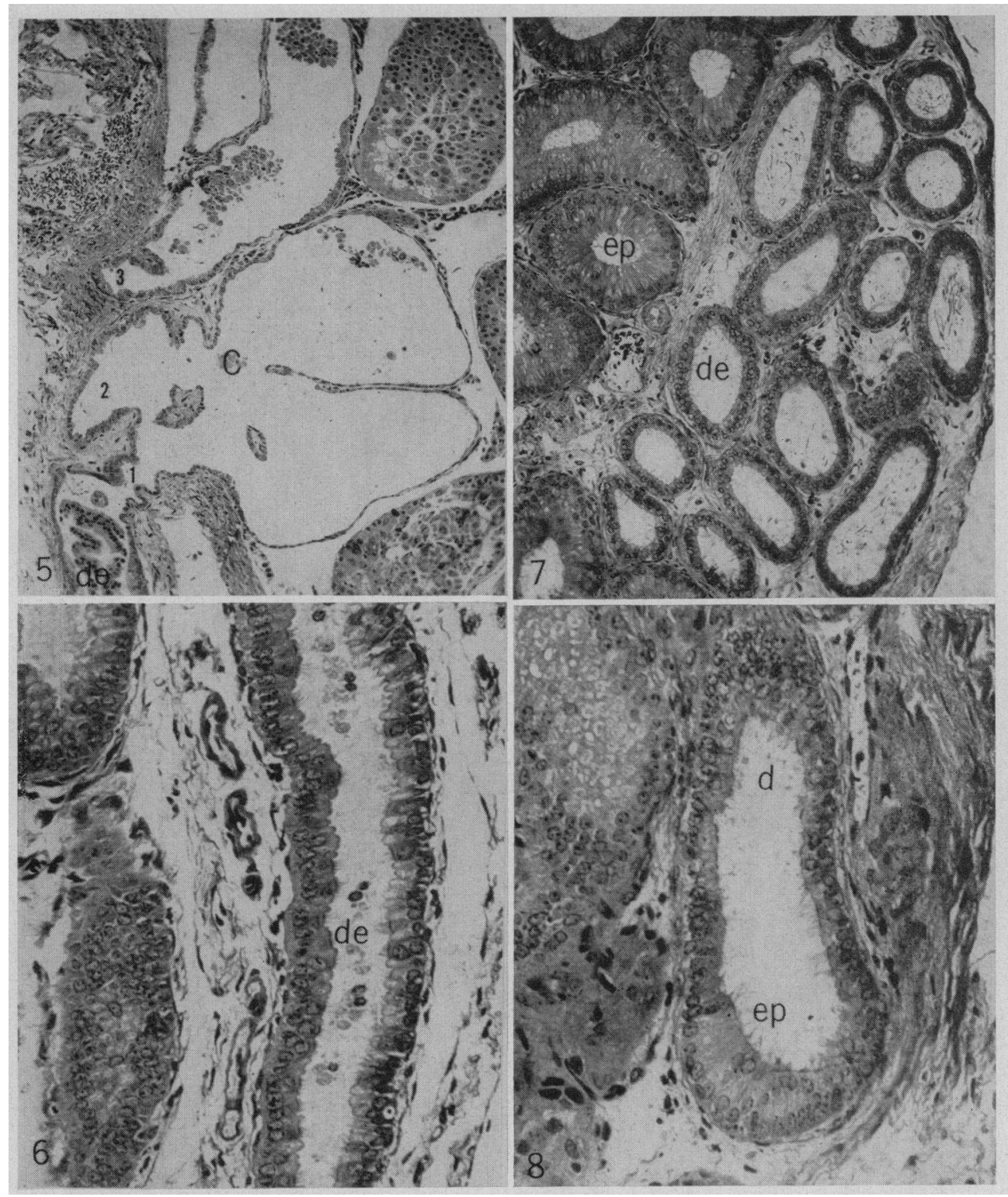

Fic, 5. The large rete channels form a single rete cavity (C) which penetrates the tunica albuginca and divides into several narrow, anastomosing channels $(1,2,3)$. The latter (1) extend beyond the tunica and are continuous with the ductuli efferentes $(\mathrm{de}) . \times 120$.

Fig. 6. 'The ductuli efferentes (de) run a zig-zag course in the mesotestis where they are surrounded by several layers of smooth muscle cells. 'The epithelium of the ductuli is composed of both ciliated and non-ciliated cells. $\times 330$.

Fro. 7. In the epididymis, the low columnar epithelium of the ductuli efferentes (de) is casily differentiated from the tall pseudostratified ciliated columnar epithclium of the duct of the epididymis $(\mathrm{ep}) . \times 160$.

lis. 8. The ductuli anastomose to form a single duct (d) in the epididymis. This single duct then becomes continuous with the duct of the epididymis $(\mathrm{e} p) . \times 310$. 
and courses distally into a large rete channel, is lined by a low cuboidal epithelium characteristic of the entire rete. The lumen of the rete extension is slightly dilated at its junction with the straight tubule. Ciliated cells do not occur in the rete extension. The small, flat, continuous layer of squamous cells characteristically seen surrounding the seminiferous tubules appears intact throughout the straight tubule and the rete extension. It was not possible to discern if this layer was intact throughout the larger rete channels. The rete extensions and the larger rete channels form the intratesticular rete.

The larger rete channels, located immediately subjacent to the tunica albuginea, follow a longitudinal anastomosing course on the medial aspect of the testis. Small groups of ciliated cells infrequently are dispersed throughout these channels and the low cuboidal epithelium can be seen to approximate to a simple squamous epithelium in some places. Immediately superior and subjacent to the point of penetration of the tunica albuginea by the testicular vessels, several of these larger rete channels converge to form a single cavity which penetrates the tunica albuginea. Within the tunica this cavity ramifies into three to five narrow anastomosing channels which constitute the intratunical portion of the rete. These latter channels extend a short distance beyond the tunica as the extra-testicular rete and are continuous with the ductuli efferentes.

The beginnings of the ductuli are recognized by an abrupt transition to a simple columnar epithelium composed of both ciliated and non-ciliated cells. The three to five ductuli are surrounded by several layers of smooth muscle cells throughout their course in the mesotestis. On entering the head of the epididymis they anastomose into a single duct which then becomes continuous with the duct of the epididymis. The initial segment of the latter is lined by a tall pseudostratified ciliated columnar epithelium.

\section{Discussion}

The histology and structure of the tubuli recti, the rete testis and the ductuli efferentes in the adult mouse have not been well documented. Benoit (1926) recognized the superficial position of the rete and described three to seven ductuli efferentes originating from that portion of the rete extending beyond the tunica. Fekete (1956) described the rete testis as an anastomosing system of canals which are lined by simple, low cuboidal or flattened epithelium and which converge to form a single lacuna. External to the tunica, this single lacuna divides into several channels each of which becomes continuous with one of the ductuli efferentes. The three to five ductules are described as lined by alternating groups of tall and low columnar epithelial cells. The work of these two investigators summarizes the knowledge of the region between the seminiferous tubules and the ductuli efferentes in the mouse. The work of Roosen-Runge (1961) has documented in detail this region in the rat. His observations correlate closely with those of Perey, Clermont \& Leblond (1961) and Marin-Padilla (1964) as to the structure of the region between a seminiferous tubule and a rete extension although there is no consistency in the use of terminology.

The present study indicates that the histology and structure of the region between the seminiferous tubule and the rete extension in the mouse are similar 
to that of the rat as reported by Roosen-Runge (1961) and therefore his terminology is used in this paper. The finding of both patent and non-patent straight tubules in the mouse is consistent with the latter's suggestion that transport of spermatozoa from the seminiferous tubules to the rete extension is a discontinuous phenomenon.

At present it seems questionable to designate as a specific anatomical entity the initial dilated segment of the rete extension. This portion of the rete extension has been referred to as 'the receptacle' by Marin-Padilla (1964). Probably the dilatation results simply from the initial communication between the straight tubule and the rete extension and the subsequent protrusion of the cytoplasmic processes of the Sertoli cells into the lumen of the rete extension. There is no evidence attributing a specific function to this initial dilated segment and the epithelium throughout the entire rete extension is identical.

As the entire rete testis of the mouse was not examined in this study a complete comparison with the rete testis of the rat is not possible. The intratesticular rete of the mouse is not, however, a single cavity as described for the rat by Roosen-Runge (1961). Several large rete channels joined by smaller rete extensions were repeatedly observed in the tissue studied. It is possible that these larger channels do anastomose as the rete progresses cranially and caudally in the testis. While small groups of cells possessing numerous cilia were found occasionally in the larger rete channels, no cells possessing a single cilium were observed as reported by Leeson (1962) in the rat.

It would appear that the intra-tunical portion of the rete in the mouse is relatively more compact than it is in the rat where long, oblique channels through the tunica have been observed by Roosen-Runge (1961). In the mouse, the narrow, anastomotic channels course almost directly through the tunica.

The extra-testicular rete in the mouse, initially enclosed by a connective tissue reflection from the tunica albuginea, extends only a short distance beyond the tunica before becoming continuous with the ductuli efferentes. In the rat, the extra-testicular rete has been observed to extend to the cranial end of the testis (Roosen-Runge, 1961). A similar cranial extension has also been reported in the hamster (Mason \& Shaver, 1952).

The tall and low columnar epithelial cells of the ductuli efferentes described by Fekete (1956) appear to correspond to the ciliated and non-ciliated cells observed in this study. The epithelium of the ductuli efferentes in the mouse is thus similar to that of the guinea-pig (Ladman \& Young, 1958) and the hamster (Burgos, 1957). The observation here that the ductuli join to form a single duct in the epididymis which then becomes continuous with the duct of the epididymis is in agreement with the findings of Benoit (1926), Young (1933) and Fekete (1956).

PART 2:

\section{TRANSPORT OF SPERMATOZOA WITHIN THE MOUSE TESTIS}

\section{Material and methods}

Animals in which the ductuli efferentes were to be ligated were anaesthetized by an intraperitoneal injection of $0 \cdot 1 \mathrm{ml} / 10 \mathrm{~g}$ body weight of a $2.5 \%$ solution of Avertin (tribromoethanol). The testis and epididymis were delivered through a 
small incision in the lower lateral abdominal wall by applying traction to the epididymal fat pad. The ductuli efferentes were located in the mesotestis immediately superior to the testicular vessels in close proximity to the testis and ligated. The ductuli were ligated with a single silk suture on the left and right sides in alternate animals except as noted below. A suture was passed through the mesotestis but the ductuli were not ligated in animals which were sham operated. After the testis and epididymis were returned to the abdominal cavity and manipulated back into the scrotum, the incision was closed. The entire operation was performed under aseptic conditions and required less than $8 \mathrm{~min}$ from administration of the anaesthetic to complete closure, with the testis and epididymis being exposed less than $1 \mathrm{~min}$. Animals were killed 1, 2 or 4 days after surgery, both testes were removed and, utilizing dissecting glasses, were trimmed to the tunica albuginea with a razor blade. The trimmed testes were placed in pre-weighed Coors porcelain crucibles and weighed on a Mettler analytic balance to the nearest $0.1 \mathrm{mg}$. A $10-\mathrm{mg}$ or greater increase in the wet weight of the operated testis over the control testis, and a lack of testicular or epididymal haemorrhage were used as criteria for a successful ligation. By these criteria $90 \%$ of the ligations were adequate.

Cryptorchid animals used in this study were $\mathrm{C} 3 \mathrm{H}$ mice bred in our laboratory and made unilaterally cryptorchid on the left side in the following manner. An incision was made through the skin and the tunica vaginalis and the ligamentum testis was severed. The testis and epididymis were manoeuvred into the abdominal cavity through the processus vaginalis around which a ligature was placed to prevent re-descent. The animals were allowed to remain cryptorchid for 8 weeks before the ductuli efferentes of the cryptorchid testis were ligated.

The ductuli efferentes were ligated on alternate sides for 1 day in fourteen adult hypophysectomized animals which had been allowed to stabilize for 4 to 6 weeks.

In all experiments the ligated and control testes of each animal were fixed in Bouin's solution, dehydrated in cellosolve and methylsalicylate and embedded in paraffin. Eight-micron skip sections were cut on a Porter-Blum microtome and stained with haematoxylin and eosin for microscopic examination.

\section{Gross findings}

On gross examination the ligated testis was more tense and turgid than its control in all normal animals. Testes which had been ligated for 4 days demonstrated these changes to a greater extent than those ligated for 2 days and 1 day respectively. No alteration of the blood supply of the ligated testis was observed grossly or microscopically. Indian ink solution injected beneath the tunica albuginea in several animals revealed similar patterns of lymphatic vessels draining both control and ligated testis. No attempt was made to measure testicular blood or lymph flow.

\section{Histological observations}

The histological and cytological changes in the testis of mice following ligation have been described by Baillie (1962) and will be only briefly discussed. 
Histologically the changes in the 1-day ligated testis of normal animals consisted of a generalized dilatation of the seminiferous tubules, the tubuli recti and the rete testis and a thinning of the seminiferous epithelium which was normal in cytological appearance. No disruption of spermatogenesis was observed and the interstitial tissue appeared normal. Examination of skip sections of each testis suggested that the lumina of more tubuli recti were patent in ligated testes than in controls. This observation was more apparent in 4-day ligated testes.

Histological changes in testes of normal animals ligated for 2 and 4 days, respectively, consisted of a greater dilatation of the seminiferous tubules, tubuli recti and rete testis and a more marked degree of thinning of the seminiferous epithelium. Varying degrees of shedding of the seminiferous epithelium into the lumina of the seminiferous tubules were observed. Desquamated cells in the lumen included both degenerated and cytologically normal components of the seminiferous epithelium. Although the spermatogenic wave was disrupted in all tubules examined, isolated segments of most tubules undergoing normal spermatogenesis were easily located. No consistent alterations or degenerative changes were observed in the interstitial tissue.

\section{Weight differences}

Data obtained from eighteen control animals are represented in Table 1. A $t$-test for paired data showed the difference in wet weight between the two testes to be significantly different at the 0.01 level although the left testis was

TABLE 1

RESULTS OF $t$-TEST FOR PAIRED DATA: COMPARISON OF LEFT AND RIGHT TESTIS WEIGHT (mg) IN GONTROL ANIMALS

\begin{tabular}{c|c|c|c|c|c|c}
\hline $\begin{array}{c}\text { No. of } \\
\text { animals }\end{array}$ & $\begin{array}{c}\text { Mean } \\
\text { testis weight } \\
\pm S . D .\end{array}$ & $\begin{array}{c}\text { Mean left } \\
\text { testis weight } \\
\pm S . D .\end{array}$ & $\begin{array}{c}\text { Mean right } \\
\text { testis weight } \\
\pm S . D .\end{array}$ & $\begin{array}{c}\text { Mean } \\
\text { difference } \\
\pm S . D .\end{array}$ & $\mathrm{t}$ & $\mathrm{P}$ \\
\hline 18 & $\begin{array}{c}109.5 \\
\pm 14.0\end{array}$ & $\begin{array}{c}107.8 \\
\pm 14.3\end{array}$ & $\begin{array}{c}111.1 \\
\pm 14.0\end{array}$ & $\begin{array}{c}3.4 \\
\pm 5.0\end{array}$ & 2.95 & $<0.01$ \\
\hline
\end{tabular}

heavier than the right in three of the eighteen animals. No significant difference between the operated and control testis in eight sham-operated animals was observed. The mean testicular weight of the sham-operated animals was not significantly different from that of the control group.

Table 2 summarizes pertinent information and data from Exps. 1 to 13. These experiments are referred to in subsequent tables by the experiment number in Table 2. To be noted in Table 2 is the fact that with the exceptions of Exps. 2 and 3, the differences in wet weight between operated and unoperated testes after ligation are within \pm 1 s.D. of each other.

A $t$-test for unpaired data showed no significant difference between the weight of the unoperated or control testis in Exps. 1 to 3 and the mean testicular weight as computed from both testes in control animals. Variances between these groups were found to be homogeneous. These results are shown in Table 3. 


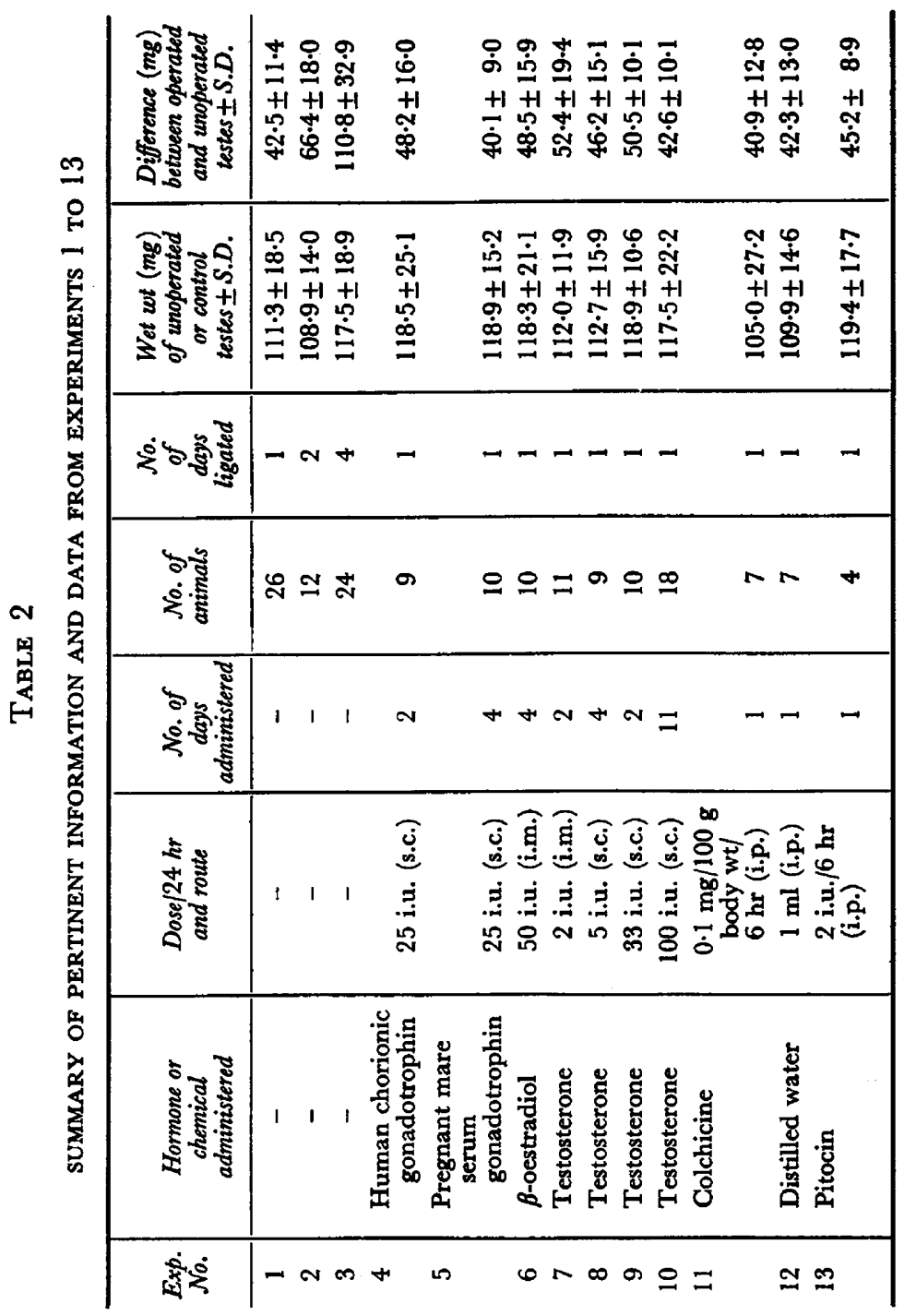


In contrast to the results in Table 3 are those in Table 4 . Here, the differences in weight between ligated and unligated testes in Exps. 1 to 3 were found to be significantly different from that of the two testes in control animals at the 0.001 level. The differences in weight observed in Exps. 1 to 3 (ligated for 1, 2 and 4 days, respectively) were also noted to be significantly different from each other at the 0.001 level. When the mean weight of the control testes in Exp. 1 was tested against the mean weight of the control testes in experimental groups 4 to 13 , no significant differences were observed at the 0.05 level. Variances between these groups were also found to be homogeneous. These results are shown in Table 5.

TABLE 3

RESULTS OF TEST FOR HOMOGENEITY OF VARIANCE (F) AND $t$-TEST FOR UNPAIRED DATA: MEAN TESTIGULAR WEIGHT (mg) OF CONTROL ANIMALS VERSUS WEIGHT OF CONTROL TESTIS IN EXPERIMENTS 1 TO 3

\begin{tabular}{c|c|c|c|c}
\hline $\begin{array}{c}\text { Control testis } \\
\text { of Exp. No. }\end{array}$ & $F$ & $\mathbf{P F}$ & $\mathbf{t}$ & $\mathbf{P t}$ \\
\hline 1 & 1.76 & $P>0.20$ & 0.36 & $P>0.70$ \\
2 & 1.01 & $P>0.50$ & 0.11 & $P>0.70$ \\
3 & 1.83 & $P>0.05$ & 1.54 & $P>0.10$ \\
\hline
\end{tabular}

TABLE 4

RESULTS OF $t$-TEST FOR UNPAIRED DATA: DIFFERENCES (mg) FOLLOWING LIGATION BETWEEN TESTES IN EXPERIMENTS 1 TO 3 VERSUS DIFFERENGES (mg) BETWEEN TESTES IN CONTROL ANIMALS AND EAGH OTHER

\begin{tabular}{|c|c|c|c|c|c|c|}
\hline \multirow{2}{*}{$\begin{array}{c}\text { Differences } \\
\text { between testes } \\
\text { in Exp. No. }\end{array}$} & \multicolumn{2}{|c|}{$\begin{array}{l}\text { Differences between } \\
\text { testes in controls }\end{array}$} & \multicolumn{2}{|c|}{$\begin{array}{l}\text { Differences between } \\
\text { testes in Exp. } 1\end{array}$} & \multicolumn{2}{|c|}{$\begin{array}{l}\text { Differences between } \\
\text { testes in Exp. } 2\end{array}$} \\
\hline & $\mathbf{t}$ & $\mathbf{P t}$ & $\mathbf{t}$ & $\mathrm{Pt}$ & $\mathrm{t}$ & $\mathbf{P t}$ \\
\hline $\begin{array}{l}1 \\
2 \\
3\end{array}$ & $\begin{array}{l}18 \cdot 67 \\
12 \cdot 78 \\
16 \cdot 49\end{array}$ & $\begin{array}{l}P<0.001 \\
P<0.001 \\
P<0.001\end{array}$ & $\begin{array}{r}\overline{-} \\
9 \cdot 99 \\
9 \cdot 97\end{array}$ & $\begin{array}{l}P<\overline{0.001} \\
P<0.001\end{array}$ & $\begin{array}{c}\overline{-} \\
\overline{4} \cdot 34\end{array}$ & $P<\overline{0.001}$ \\
\hline
\end{tabular}

In Table 6, the results of testing the mean difference between ligated and control testes from animals in Exp. 1 against the mean difference between ligated and control testes from animals in Exps. 4 to 13 are shown. Again no significant differences at the 0.05 level were found and, with the exception of Exp. 7 , the variances between these groups were homogeneous. In order to test the mean difference in Exp. 1 with that of Exp. 7, $t$ was calculated by the usual formula and the $t$-table was entered with half the usual number of degrees of freedom (Snedecor, 1956). Reference to Table 2 reveals that all of the results reported in Tables 5 and 6 are from experimental groups consisting of 1-day ligated animals.

The mean control (unoperated) testis weight in the hypophysectomized 
animals was $14.1 \pm 3.0 \mathrm{mg}$ as compared to a mean testicular weight of 109.5 $\pm 14.0 \mathrm{mg}$ in the 8 -week control animals (Table 1). A $t$-test for paired data showed the mean weight of the ligated testis to be significantly different from the mean weight of the control (unligated) testis at the 0.005 level (Table 7). In no animal was the weight of the control testis greater than that of the ligated testis.

\section{TABLE 5}

RESULTS OF TEST FOR HOMOGENEITY OF VARIANGE (F) AND $t$-TEST FOR UNPAIRED DATA: COMPARISON OF THE MEAN TESTICULAR WEIGHT (mg) OF THE CONTROL TESTIS IN EXPERIMENT 1 WITH THE MEAN CONTROL TESTIS WEIGHT (mg) IN EXPERIMENTS 4 To 13

\begin{tabular}{c|c|c|c|c}
\hline $\begin{array}{c}\text { Control testis } \\
\text { of Exp. No. }\end{array}$ & $F$ & $\mathrm{PF}$ & $\mathrm{t}$ & $\mathrm{Pt}$ \\
\cline { 2 - 3 } & & & \\
\hline 4 & 1.84 & $P>0.20$ & 0.91 & $P>0.30$ \\
5 & 1.48 & $P>0.50$ & 1.15 & $P>0.20$ \\
6 & 1.30 & $P>0.50$ & 0.97 & $P>0.30$ \\
7 & 2.43 & $P>0.05$ & 0.10 & $P>0.90$ \\
8 & 1.36 & $P>0.50$ & 0.20 & $P>0.80$ \\
9 & 3.03 & $P>0.05$ & 1.22 & $P>0.20$ \\
10 & 1.44 & $P>0.20$ & 1.00 & $P>0.30$ \\
11 & 2.15 & $P>0.05$ & 0.73 & $P>0.40$ \\
12 & 1.60 & $P>0.50$ & 0.17 & $P>0.80$ \\
13 & 1.10 & $P>0.50$ & 0.81 & $P>0.40$ \\
\hline
\end{tabular}

TABLE 6

RESULTS OF TEST FOR HOMOGENEITY OF VARIANCE (F) AND $t$-TEST FOR UNPAIRED DATA: COMPARISON OF THE DIFFERENGES (mg) BETWEEN TESTIS IN EXPERIMENT 1 WITH THE DIFFERENGES (mg) BETWEEN TESTES IN EXPERIMENTS 4 TO 13

\begin{tabular}{c|c|c|c|c}
\hline $\begin{array}{c}\text { Differences } \\
\text { between testis } \\
\text { of Exp. No. }\end{array}$ & $F$ & $\mathrm{PF}$ & $\mathrm{t}$ & $\mathrm{Pt}$ \\
\hline 4 & 1.97 & $P>0.05$ & 1.18 & $P>0.20$ \\
5 & 1.61 & $P>0.20$ & 0.60 & $P>0.50$ \\
6 & 1.95 & $P>0.05$ & 1.28 & $P>0.20$ \\
7 & 2.91 & $P<0.05$ & 1.95 & $P>0.05$ \\
8 & 1.77 & $P>0.20$ & 0.79 & $P>0.40$ \\
9 & 1.26 & $P>0.50$ & 1.95 & $P>0.05$ \\
10 & 1.28 & $P>0.50$ & 0.05 & $P>0.95$ \\
11 & 1.27 & $P>0.50$ & 0.32 & $P>0.70$ \\
12 & 1.30 & $P>0.50$ & 0.00 & $P>0.0005$ \\
13 & 1.63 & $P>0.50$ & 0.45 & $P>0.60$ \\
\hline
\end{tabular}

In Table 8 the results of experiments performed on twenty $\mathrm{C} 3 \mathrm{H}$ animals which had been made unilaterally cryptorchid on the left side at 4 to 5 weeks of age are reported. These animals were allowed to stabilize for 8 weeks before they were used in subsequent experiments. At this time the animals were divided at random into an experimental and a control group. The ductuli efferentes 
were ligated on the cryptorchid side in the experimental group and the animals were killed 1 day after operation. The control group of animals was killed at the same time. A $t$-test for unpaired data revealed no significant difference between the mean control testis weight of the control group and the mean control testis weight of the experimental group. The mean difference between the cryptorchid and control (right) testis in the control group was also statistically insignificant from the mean difference between the ligated cryptorchid testis and control (right) testis in the experimental group.

\section{TABLE 7}

RESULTS OF $t$-TEST FOR PAIRED DATA: COMPARISON OF THE WEIGHT (mg) OF THE LIGATED AND CONTROL TESTIS IN HYPOPHYSECTOMIZED ANIMALS

\begin{tabular}{c|c|c|c|c|c}
\hline $\begin{array}{c}\text { No. } \\
\text { of } \\
\text { animals }\end{array}$ & $\begin{array}{c}\text { Mean weight } \\
\text { ligated testis } \\
\pm S . D .\end{array}$ & $\begin{array}{c}\text { Mean weight } \\
\text { control testis } \\
\pm S . D .\end{array}$ & $\begin{array}{c}\text { Mean } \\
\text { difference } \\
\pm S . D .\end{array}$ & $\mathbf{t}$ & $\mathrm{Pt}$ \\
\hline 14 & $\begin{array}{c}16.3 \\
\pm 3.5\end{array}$ & $\begin{array}{c}14 \cdot 1 \\
\pm 3.0\end{array}$ & $\begin{array}{c}2 \cdot 2 \\
\pm 2 \cdot 4\end{array}$ & 3.41 & $P<0.005$ \\
\hline
\end{tabular}

TABLE 8

RESULTS OF TEST FOR HOMOGENEITY OF VARIANGE (F) AND $t$-TEST FOR UNPAIRED DATA: COMPARISON OF THE MEAN GONTROL TESTIS WEIGHT (mg) AND THE DIFFERENCE (mg) BETWEEN TESTES IN THE CONTROL AND EXPERIMENTAL. GROUPS OF GRYPTORCHID ANIMALS

\begin{tabular}{c|c|c|c|c|c|c}
\hline $\begin{array}{c}\text { No. } \\
\text { of } \\
\text { animals/ } \\
\text { group }\end{array}$ & $\begin{array}{c}\text { Mean control } \\
\text { testis weight } \\
\text { of control } \\
\text { group } \pm \text { S.D. }\end{array}$ & $\begin{array}{c}\text { Mean control } \\
\text { testis weight } \\
\text { of experimental } \\
\text { group } \pm \text { S.D. }\end{array}$ & $F$ & $\mathrm{PF}$ & $\mathrm{t}$ & $\mathrm{Pt}$ \\
\hline 10 & $\begin{array}{c}82.56 \\
\pm 7.86\end{array}$ & $\begin{array}{c}81.98 \\
\pm 6.32\end{array}$ & 1.55 & $P>0.50$ & 0.18 & $P>0.80$ \\
\hline
\end{tabular}

\begin{tabular}{c|c|c|c|c|c|c}
\hline $\begin{array}{c}\text { No. } \\
\text { of } \\
\text { animals/ } \\
\text { group }\end{array}$ & $\begin{array}{c}\text { Mean difference } \\
\text { between testes } \\
\text { in control } \\
\text { group } \pm \text { S.D. }\end{array}$ & $\begin{array}{c}\text { Mean difference } \\
\text { between testes } \\
\text { in experimental } \\
\text { group } \pm \text { S.D. }\end{array}$ & $F$ & $\mathrm{PF}$ & $\mathrm{t}$ & $\mathrm{Pt}$ \\
\hline 10 & $\begin{array}{c}39.29 \\
\pm 15.75\end{array}$ & $\begin{array}{c}35.06 \\
\pm 14.32\end{array}$ & 1.21 & $P>0.50$ & 0.63 & $P>0.50$ \\
\hline
\end{tabular}

\section{Discussion}

The significance of the finding in this study that the right testis was slightly heavier than the left is not known. Other investigators, including Baillie (1962) who compared the weight of the left and right testis following unilateral ligation of the epididymis, have not made this observation. The fact that no significant difference in weight between the two testes was observed in eight sham-operated animals suggests that the control finding may be a chance phenomenon. Further 
data must be accumulated before this apparent weight difference can be confirmed.

The wet weight differences between the two testes observed 1,2 and 4 days after unilateral ligation of the ductuli were $42.5 \pm 11.4 \mathrm{mg}, 66.4 \pm 18.0 \mathrm{mg}$ and $110.8 \pm 32.9 \mathrm{mg}$, respectively. Fluid accumulation thus began to plateau at a maximum of 2 days after ligation. It was, therefore, concluded that the $42.5 \pm$ $11.4 \mathrm{mg}$ difference observed 1 day after ligation of the ductuli represented the most accurate estimate of the weight of the fluid flowing through the seminiferous tubules, the tubuli recti and the rete testis in a given period of time.

Hirota (1952) teased apart the seminiferous tubules in seven testes from five adult mice and reported an average total tubular length of $179.2 \mathrm{~cm}$ and a maximum tubular diameter of $0.26 \mathrm{~mm}$. Assuming the geometric shape of the tubules to conform closely to that of a cylinder and the maximum average radius of the lumen of the tubules to be $0.065 \mathrm{~mm}$ or one-half the maximum radius of the tubules, a maximum volume capacity of the lumen of the seminiferous tubules was calculated and found to be $23.8 \mathrm{~mm}^{3}$. (This figure does not include the volume of the intratesticular rete which cannot be estimated at this time.)

Unfortunately, the specific gravity of the seminiferous fluid in the mouse has not been determined. It may be assumed, however, that it lies between that of water (1.000) and that of concentrated sulphuric acid (1.841). Normal plasma, for instance, has a specific gravity equal to 1.010 . If the $42.5 \mathrm{mg}$ of fluid accumulating/day is assumed to have a specific gravity of 1.841 (completely outside the normal physiological range), the volume of fluid flowing through the seminiferous tubules/day is calculated to be $23 \cdot 1 \mathrm{~mm}^{3}$. Such a figure reveals that the seminiferous tubules are completely flushed approximately once/day or eight times/spermatogenic cycle, estimated by Oakberg (1956) to be $8.63 \pm$ 0.26 days in the mouse. Admittedly the above calculations are, at best, rough estimates. Nonetheless, the significance of the rapid fluid flow through the seminiferous tubules to the mechanism of transport of spermatozoa from the seminiferous tubules to the ductuli efferentes is clearly evident. Such a rapid fluid flow also explains the relatively few spermatozoa free in the lumen of the seminiferous tubules, the tubuli recti, the rete testis and the ductuli efferentes.

The origin of this intratubular fluid can only be speculated on at present. Data presented above indicated the failure of numerous hormones including testosterone and also distilled water to influence the amount of fluid accumulating after ligation of the ductuli efferentes. The failure of colchicine to alter the fluid accumulation suggests that the origin is not dependent on those cells in the seminiferous epithelium undergoing mitosis. However, only spermatogonia can be eliminated on this supposition.

Antliff \& Young (1957) concluded that after 3 years of cryptorchidism, the endocrine activity of the testes in the guinea-pig was not reduced sufficiently to interfere with the maintenance of the epididymis, the seminal vesicles or the prostate. Their results clearly indicate that testosterone is secreted by a cryptorchid testis. In the present study no fluid accumulation was observed in a cryptorchid testis. It therefore can be surmised that the presence of testosterone alone is not sufficient to maintain intratubular fluid flow; of interest, 
in this regard, are the observations of Clegg \& Macmillan (1965) in which they report differences in the uptake of Trypan Blue by the seminiferous epithelium in normal and cryptorchid mature rats when the dye is introduced directly into the seminiferous tubules.

Clermont \& Morgentaler (1955) reported the development of a few spermatids to step 7 of spermiogenesis in rats which had been hypophysectomized for 61 days. They concluded that spermatogenesis could proceed to step 7 of spermiogenesis in the absence of hypophysial hormone stimulation. Nelson \& Merckel (1938) reported the maintenance of complete spermatogenesis in hypophysectomized mice with injections of androgenic hormones. The present study indicates that intratubular fluid flow does occur to a limited extent in mice hypophysectomized for 4 to 6 weeks. These results suggest that the maintenance of an intratubular fluid flow is dependent upon some unknown interaction occurring early in spermiogenesis (steps 1 to 7 ) in which testosterone is not required.

Vilar, del Cerro \& Mancini (1962), suggested that the Sertoli cell may play an important role in the transfer of material between intertubular vessels and germinal cells. Elftman (1963) emphasized the arrangement of the germinal cells in relation to the Sertoli cells and suggested that the latter may exert an influence on germ cell maturation. Lacy (1962) postulated a Sertoli cell hormone, dependent on the shedded cytoplasm of maturing spermatids and FSH for synthesis and/or secretion, to act locally particularly during steps 9 to 14 of spermatogenesis. Christensen (1965) reported the observation of microtubules in the cytoplasm of Sertoli cells and in nearby germinal cells undergoing spermatogenesis. The observations of these investigators emphasize the close association and possible interaction between the Sertoli cell and germinal cells particularly during spermiogenesis. These observations and the results of the present study suggest that the Sertoli cell is the source of the intratubular fluid required for the transport of immotile spermatozoa from the seminiferous tubules to the ductuli efferentes. It is further hypothesized that the initiation and maintenance of secretion of this fluid by the Sertoli cell is brought about by some interaction, which is independent of testosterone, between the Sertoli cell and its associated spermatids in early spermiogenesis.

\section{ACKNOWLEDGMENTS}

The author wishes to express his appreciation to Dr A. Duncan Chiquoine for his constant encouragement and support of this project, and to $\mathrm{Mr} \mathrm{W}$. W. Rhoades for his photographic assistance in the preparation of the plates. Hormones and chemicals were purchased from Sigma Chemical Company. Hypophysectomized mice were purchased from Charles Rivers Company.

This work was supported in part by Grants GM-03784 and GM-00240 from the Institute of General Medical Sciences, and by Grant 5R01-HD-01050 from the National Institute of Child Health and Human Development, National Institutes of Health, Bethesda, Maryland. 


\section{REFERENCES}

Anturf, H. R. \& Young, W. C. (1957) Internal secretory capacity of the abdominal testis in the guinea pig. Endocrinology, 61, 121.

BaIlliE, A. H. (1962) Observations comparing the effects of epididymal obstruction at various levels on the mouse testis with those of ischaemia. F. Anat. 96, 335.

Benort, M. J. (1926) Recherches anatomiques, cytologiques et histologiques sur les voies excretrices du testicule, chez les mammifères. Archs Anat. microsc. 5, 175.

Burgos, M. H. (1957) Fine structure of the efferent ducts of the hamster testis. (Abstract). Anat, Rec. 127,401

Christensen, K. A. (1965) Microtubules in Sertoli cells of the guinea pig testis. (Abstract). Anat. Rec. $151,335$.

Clegg, E. J. \& Macmillan, E. W. (1965) The uptake of vital dyes and particulate matter by the Sertoli cells of the rat testis. F. Anat. 99, 219.

Clermont, Y. (1958) Contractile elements in the limiting membrane of the seminiferous tubules of the rat. Expl Cell Res. 15, 438.

Clermont, Y. \& Morgentaler, H. (1955) Quantitative study of spermatogenesis in the hypophysectomized rat. Endocrinology, 57, 369.

Elftman, H. (1963) Sertoli cell and testis structure. Am. F. Anat. 113, 25.

FeKete, E. (1956) Histology. In: The Biology of the Laboratory Mouse. Ed. G. D. Snell. Blakiston, Philadelphia.

Gaddum, P. \& Glover, T. D. (1965) Some reactions of rabbit spermatozoa to ligation of the epididymis. 7. Reprod. Fert. 9, 119.

Harrison, R. G. (1953) The effect of ligation of the vasa efferentia on the rat testis. Proc. Soc. Study Fert. $5,97$.

Harrison, R. G. \& Macmillan, E. W. (1954) The effects of high epididymal obstruction upon the Leydig cell volume of the rat testis. F. Endocr. 11, 89.

Hirota, S. (1952) The morphology of the seminiferous tubules. I. The seminiferous tubules of the mouse. Kyushu Mem. med. Sci. 3, 121.

Holstein, A. R. \& Werss, C. L. (1967) Uber die Wirkung der glatten Muskulatur in der Tunica Albuginea im Hoden des Kaninchens; Messungen des intertitiellen Druakes. Z.ges. exp. Med. $142,334$.

LACY, D. (1962) Certain aspects of testis structure and function. Br. med. Bull. 18, 205.

LADMAN, A. J. \& YounG, W. C. (1958) Electron microscopic study of the ductuli efferentes and the rete testis of the guinea pig. 7. biophys. biochem. Cytol. 4, 219.

LeEson, T. S. (1962) Electron microscopy of the rete testis of the rat. Anat. Rec. 144, 57.

MaGmillan, E. W. \& AukLand, J. (1960) The transport of radiopaque medium through the initial segment of the rat epididymis. F. Reprod. Fert. 1, 139.

Macmillan E. W. \& HarRison, R. G. (1955) The rate of passage of radiopaque medium along the ductus epididymidis of the rat. Stud. Fert. 7, 35.

Marin-Padilla, M. (1964) The mesonephric-testicular connection in man and some mammals. Anat. Rec. 148, 1.

Mason, K. E. \& Shaver, S. L. (1952) Some functions of the caput epididymis. Ann. N.Y. Acad. Sci. 55, 585.

Nelson, W. O. \& Merckel, C. E. (1938) Maintenance of spermatogenesis in hypophysectomized mice with androgenic substances. Proc. Soc. exp. Biol. Med. 38, 737.

OAKBERG, E. F. (1956) Duration of spermatogenesis in the mouse and timing of stages of the cycle of the seminiferous epithelium. Am. 7. Anat. 99, 507.

Perey, B., Clermont, Y. \& Leblond, C. P. (1961) The wave of the seminiferous epithelium in the rat. Am. F. Anat. 108, 47.

Roosen-RUNGe, E. C. (1961) The rete testis in the albino rat; its structure, development and morphological significance. Acta anat. 45, 1.

Scott, T. W., Wales, R. G., Wallace, J. C. \& White, I. G. (1963) Composition of ram epididymal and testicular fluid and the biosynthesis of glycerophosphorylcholine by the rabbit epididymis. 7. Reprod. Fert. 6, 49.

SNedecor, G. W. (1956) Statistical methods, 5th edn, p. 97. Iowa State College Press, Ames, Iowa.

Tоотнill, M. G. \& Young, W. C. (1931) The time consumed by spermatozoa in passing through the ductus epididymis of the guinea pig as determined by means of India ink injections. Anat. Rec. $50,95$.

VAN WAGENEN, G. (1924) Degeneration of germinal epithelium in the testis of the rat as a result of efferent duct ligation. (Abstract). Anat. Rec. 27, 189.

VAN WAGENEN, G. (1925) Changes in the testis of the rat following ligation of the ductuli efferentes. (Abstract). Anat. Rec. 29, 399. 
Vuar, O., del Gerro, M. I. P. \& Mancini, R. E. (1962) Sertoli cell as a "bridge cell" between the basal membrane and the germinal cells. Expl Cell Res. 27, 158.

Von MOLLENDORpr, W. (1920) Vitale farbungen an tierischen Zellen. Ergebn. Physiol. 18, 141.

WHrte, W. E. (1933) The duration of fertility and the histological changes in the reproductive organs after ligation of the vasa efferentia in the rat. Proc. $R$. Soc. B, 133, 544.

Youno, W. C. (1933) Die Resorption in den Ductuli efferentes der Maus und ihre Bedeutung fur das Problem der Unterbindung im Hoden-nebenhodensystem. Z. Zellforsch. mikrosk. Anat. 17, 729. 